
Egypt. Acad. J. biolog. Sci., 1 (1): 29-36 (2010)
Email: egyptianacademic@yahoo.com
Received: 21/6/2010
D. Histology \& Histochemistry
ISSN: $2090-0775$
www.eajbs.eg.net

\title{
Morphological evidence for possible sites of Production of the female sex pheromone of Spodoptera littoralis (Lepidoptera: Noctuidae).
}

\author{
Nasra M. H. Zohry \\ Department of Zoology Faculty of Science Sohag University, Egypt.
}

\begin{abstract}
The morphology of the female sex pheromone gland of S. littoralis was studied using scanning electron and light microscopy. This gland is situated ventrally in the intersegmental membrane just in front of the last abdominal segments, the cuticula of the intersegmental membrane between eighth and ninth segments is thickened and slightly raised, bears furrows the rim of which just in front of the ninth is covered with cuticular hairs. The second structure involved in pheromone production is a gland lies in the body cavity situated beneath the eighth and seventh abdominal tergites, as an invagination of the ventral intersegmental membrane between eighth and ninth segments. This gland leads to a duct with an eversible sac. Examination of the tissue with scanning electron microscopy showed the presence of excreted droplets at the tips of cuticular hairs in the glandular area during the period of pheromone production.
\end{abstract}

Keywords: Female sex pheromone, Lepidoptera, Spodoptera littoralis, Morphology, Scanning electron microscopy, Ultrastructure.

\section{INTRODUCTION}

Females of most moths produce species-specific sex pheromones in specialized glands, generally located on the terminal abdominal segments that constitute the ovipositor. Steinbrecht (1982) studied the location of female pheromone gland in the African armyworm moth, Spodoptera exempta. Precy-Cunningham and Macdonald (1987) identified the Pheromone glands of female moths representing 16 families and studied their structural characteristics. The majority of the species examined belong to the family Noctuidae. Among the Heliothinae, morphology and histology of the pheromone glands were studied in Heliothis virescens and Helicoverpa zea (Jefferson et al., 1968; Aubrey et al., 1983; Teal et al., 1983; PrecyCunningham and MacDonald, 1987). Percy-Cunningham and MacDonald (1987) reported on the ultrastructural features of the gland in $H$. zea. A more complete ultrastructural study of the pheromone glands was concluded in Choristoneura fumiferana (Percy, 1974) and Trichoplusia ni (Percy, 1979). In the latter case, the author also attempt to correlate ultrastructural changes to production and release of pheromone. Also, Raina et al. (2000) studied the morphological location of the sex pheromone producing area in the ovipositor of female corn earworm $H$. zea and correlated with gas chromatographic analysis of the extracted pheromone. Morphological and histological studies in the production of sex pheromone of Copitarsia consueta (Rojas et al., 1995).

The sex pheromone gland of calling female Sapodilla fruit borer (SFB), has been studied histologically (Suwanjarat and Witethom, 1995). Ma and Roelofs (2002) studied the sex pheromone gland of the female European corn borer moth, Ostrinia nubilalis using light and electron microscopy. 
The Egyptian cotton leafworm, Spodoptera littoralis, is a very important polyphagous pest but little effort has been invested in studying the exact location of the sex pheromone gland. In this paper we used the technique of scanning electron microscope and light microscope to observe morphological and histological evidence of putative cells involved in the production of sex pheromone of S. littoralis.

\section{MATERIALS AND METHODS Insect rearing}

Spodoptera littoralis (Boisd)

larvae obtained from the laboratory culture of plant protection, Research Institute, Agricultural, Research Center (Cairo, Egypt). The insects were obtained from a colony reared in the laboratory under constant laboratory conditions of $27 \pm 2 \mathrm{C}$ and $70 \pm 5 \%$ R. H. Male and female pupae were placed in separate glass jars for adult emergence. Female moths were isolated in small glass jars to avoid copulation. Adult were provided $10 \%$ sucrose solution for feeding.

Scanning electron microscopy (SEM):

The terminal portions of the abdomen of virgin females of one day old were extruded to normal degree by gentle squeezing, and the abdomen ligated to keep the last segments extruded. The abdominal tips were cut off anterior to the ligation and fixed in a solution of $1 \%$ glutraldehyde. After completion of fixation, wash the specimens in a buffer solution with $\mathrm{pH}=$ 6.8 for three times each for $20 \mathrm{~min}$. They were dehydrated in $30 \%, 50 \%, 70 \%$, $90 \%$ and $100 \%$ (three times) ethanol and each for $15 \mathrm{~min}$. After wards, they were dried at critical point and finally coated with gold using sputter coating for examination by using scanning electron microscopy (SEM), JEOL, JSM 5300.

\section{RESULTS \\ Pheromone gland location and morphology:}

Scanning electron microscopy of the integument of the last abdominal segments suggests that three types of structures are involved in the production and release of pheromonal components. In the protruded position the cuticula of the intersegmental membrane between eighth and ninth segments is thickened and slightly raised, bears furrows the rim of which just in front of the ninth segment is covered with densely cuticular hairs (Fig.1a\&b). The cuticle in the intersegmental membrane between eight and ninth segments does not show any orifices (Fig.1a\&b).The second structure involved in pheromone production is a gland lies in the body cavity situated beneath the seventh and eighth abdominal tergites, as an invagination of the ventral intersegmental between eighth and ninth segments (Fig.1c). This gland has a duct with an eversible sac which is lined by a cuticular layer with cuticular hairs or microtrichia pointing toward the lumen of the sac (Fig.1d). The female secretes the pheromone from the gland on the cavity. In the retracted position, the sac is folded in the lumen of the duct (Fig.1d). In the extruded position, or during calling, the sac with cuticular hair is everted and pushed outward and exposed to the environment (Fig. 2a). In the everted sac the cuticular hairs were different in length, density, pointed in different directions and some had a bifurcated structure (Fig.2b-f). Externally, the third structure involved in pheromone production the integument around the ninth segment (ovipositor). The ventral surface of the integument around the ninth segments was highly convoluted and had cuticular hairs which were different in length and pointed in different directions (Fig.2a). Externally, the $8^{\text {th }} \& 7^{\text {th }}$ abdominal segments do not show structures that might produce sex 
pheromone, the cuticular hairs very decrease, more sparse, covered with scales and all of them pointed posteriorly (Fig.3a).

\section{Pheromone release}

Scanning electron microscopy revealed the presence of small globules of secretion, at the bases and the tips of many of the cuticular hairs (Fig.3b-d). The secretions were observed only in the ventral area of the last abdominal segments.

\section{DISCUSSION}

From behavioral features at calling and from preliminary investigations using scanning electron microscopy and light microscopy it has already revealed that the bulk of the pheromone producing area occupied the intersegmental membrane between $8^{\text {th }}$ and $9^{\text {th }}$ segments, the gland in the abdominal cavity that attached to the intersegmental membrane between $8^{\text {th }}$ and $9^{\text {th }}$ segments and the integument around the ninth segment.

The cuticula of the intersegmental membrane between eighth and ninth segments is thickened and slightly raised, bears furrows the rim of which just in front of the ninth segment is covered with densely cuticular hairs these results agreed with that reported by Davis and Povel (1993) in female of Yponomeuta latreille. Comparable to the situation in many other Lepidoptera (Precy- Cunningham and MacDonald, 1987), the gland is dorsal scent fold in the intersegmental membrane between the eighth and ninth abdominal segments. Raspotnig et al., 2003 reported that the gland in Cameraria ohridella consists of a single layer of modified epidermal cells in the dorsal part of the intersegmental membrane between eight and ninth segments. Raina et al. (2000) showed that the pheromone gland occupied an almost complete ring of specialized columnar cells between the $8^{\text {th }}$ and $9^{\text {th }}$ abdominal segments in Helicoverpa zea. Paired glandular ducts and sacs, scent folds representing one major class of intersegmental membrane pheromone glands in female Lepidoptera (Gotz, 1951). Scent folds may occur on the ventral body side as in Yponomeuta latreille (Davis and Povel (1993)), in Spodoptera exempta (Steinbrect, 1982). Jefferson et al., 1968 reported that the gland is an eversible sac situated ventrally in the intersegmental membrane between the $8^{\text {th }}$ and $9^{\text {th }}$ abdominal segments in Spodoptera exigua and Feltia subterranean, as a pair of lateral cuticular sacs in Copitarsia consueta (Rojas et al., 1995). Hallberg and Subchev (1996) suggested that the sex pheromone glands of female Theresimima ampelophaga are situated on the anterior part of $3^{\text {rd }}-5^{\text {th }}$ abdominal tergites. Chow et al. (1976) suggested that the sex pheromone glands of female Plutella xylostella consists of a single layer of columnar cells located in three different parts these are the intersegmental folds of the $8^{\text {th }}$ and $9^{\text {th }}$ segments, the thick epidermal cells on the dorsal inner surface of the $9^{\text {th }}$ abdominal segment and the epithelium around ostium bursae. Suwanjarat and Witethom (1995) reported that the scent pheromone gland of female Sapodilla fruit borer is located dorsally and ventrally in the intersegmental membrane between the eighth and ninth segments. Yin et al., (1991) proposed that the sex pheromone from the female arctiid moth Holomelina lamae originates from a pair of internal glands located dorsally at the female's abdominal tip, above the ovipositor. However, examples for thoracal pheromone glands have also been described ( Bosman and Brand, 1971 ).

According to Davis and Povel (1993) we suggest that The cuticula of the intersegmental membrane between eighth and ninth segments is thickened and slightly raised possibly an adaptation to store lipid pheromones. The mechanism of releasing pheromones remains speculative. According to Raina et al., (2000) we suggest that droplets are sheared from the cuticular hairs that found in the glandulra area during pulsation of the abdominal tips. Raina et al., (2000) reported that pheromone or its immediate precursor, produced in the glandular cells, is transported through the cuticle onto the cuticular hairs. During calling, the area of the ovipositor bearing the pheromone gland is extruded and exposed to the outside. Presence of extensive cuticular hairs increase the surface area to facilitate the evaporation of the pheromone, when the pheromone is dissipated the ovipositor is retracted there by squeezing more 
pheromone on to exposed surface, followed by another extension. This sequence is repeated throughout the period of calling. Also, Conner et al., (1980) proposed that the spines lining the pheromone gland of Utethesia ornatrix increased the gland's surface area, as well as preventing collapse the gland as it ventilated pheromone to the gland's orifice.

\section{REFERENCES}

Aubery, J. G., Boudreaux, H. B.; Grodner, M. L. and Hammond, A. M. (1983). Sex pheromone- producing cells and their associated cuticle in female Heliothis zea and $H$. virescens (Lepidoptera: Noctuidae). Annals of the Entomological Society of America, 76: 343-348.

Bosman, T. and Brand, J. M. (1971). Biological studies of the sex pheromone of Kotochalia junodi Heyl. ( Lepidoptera: psychidae) and its partial purification. J. Entomol. Soc. S. Afr. 34: 73-78.

Chow, Y. S.; Chen, J. and Chow, S. H. (1976). Anatomy of the female sex pheromone gland of the diamondback moth, Plutella xylostella (Lepidoptera: Plutellidae).

Conner, W. E.; Eisner, T.; Vander Meer, T. K.; Guerrero, A.; Ghiringelli, D. and Meinwald, J. (1980). Sex attractant of an arctiid moth Utethesia ornatrix: a pulsed chemical signal. Behav. Biol. Sociobiol. 7: 55-63.

David, G. and Povel, E. (1993). Morphology of the female sex pheromone gland of Yponomeuta latreille (Lepidoptera: Yponomeutidae). Neth. J. Zool. Numbers (12) 44:77-84.

Gotz, B. (1951). Die sexualduftstoffe der Lepidoptera. Experientia 7: 406-418.

Hallberg, E. and Subchev, M. (1996). Unusual location and structure of female pheromone glands in Theresimima ampelophaga BsyleBerelle (Lepidoptera: Zygaenidae). Int. J. Ins. Morph. Embryol. 25(4): 381-389.

Jefferson, R.N.; Shorey, H.H. and Rubin, R. E. (1968). Sex pheromones of Noctuid moths. XVI. The female sex pheromone glands of eight species. Annals of the Entomological Society of America 61, 861-865.

Ma, P. W. and Roelofos, W. L. (2002). Sex pheromone gland of the female European corn borer moth, Ostrinia nubilalis (Lepidoptera: Pyralidae): ultrastructural and biochemical evidences. Zoolog Sci. 19(5): 501-11.
Percy, J. E. (1974). Ultrastructure of pheromone gland cells and cuticle before and during release of pheromone in female eastern spruce budworm, Choristoneura fumiferana (Clem.) (Lepidoptera: Tortricidae). Canadian Journal of Zoology, 52:695-705.

Percy, J. E. (1979). Development and ultrastructure of sex-pheromone gland cells in females of the cabbage looper moth, Trichoplusia ni (Hubner) (Lepidoptera: Noctuidae). Canadian Journal of Zoology, 57:220-236.

Percy-Cunningham, J. E. and MacDonald, J.A. (1987). Biology and ultrastructure of sex pheromone-producing glands. In : Prestwich, G. D., Blomquist, G. J. (Eds.). Pheromone Biochemistry. Academic Press, Orlando,FL,pp. 27-75.

Raina, A. K.; Wergin, W. P.; Murphy, C. A. and Erbe, E. F. (2000). Structural organization of the sex pheromone gland in Helicoverpa zea in relation to pheromone production and release. Arthropod Structural \& Development, 29: 343-353.

Raspotnig, G.; Schicho, R.; Stabentheiner, E.; Magnes, C. and Stelzl, M. (2003). Morphology of female sex pheromone gland in the horse chestnut leaf miner Cameraria ohridella (Lepidoptera: Gracillariidae). J. Appl. Ent. 127: 121-126.

Rojas, J. C.; Carrasco, J. V. and Tovar, J. C. (1995). Morphological Evidence for possible sites of production of the female sex pheromone of Copitarsia consueta (Lepidoptera: Noctuidae). Florida Entomologist, 78 (2): 360-363.

Steinbrecht, R. A. (1982). Electrophysiological assay of synthetic and natural sex pheromones in the African armyworm moth, Spodoptera exempta. Entomologia Experimentalis et Applicata, 32 (1):13-22.

Suwanjarat, J. and Witethom, B. (1995). Histology of the female sex pheromone gland of the Sapodilla Fruit Borer (Lepidoptera: Pyralidae).Science Asia 21:117-123.

Teal, P. E. A.; Carlysle, T. C. and Tumlinson, J. H. (1983). Epidermal glands in terminal abdominal segments of female $H$. virescens (F.) (Lepidoptera: Noctuidae). Annals of the Entomological Society of America, 76: 242247.

Yin, L. S. S.; Schal, C. and Carde, R.T. (1991). Sex pheromone gland of the female tiger moth Holomelina lamae ( Lepidoptera: Arctiidae). Can. J. Zool. 69: 1916-1921. 

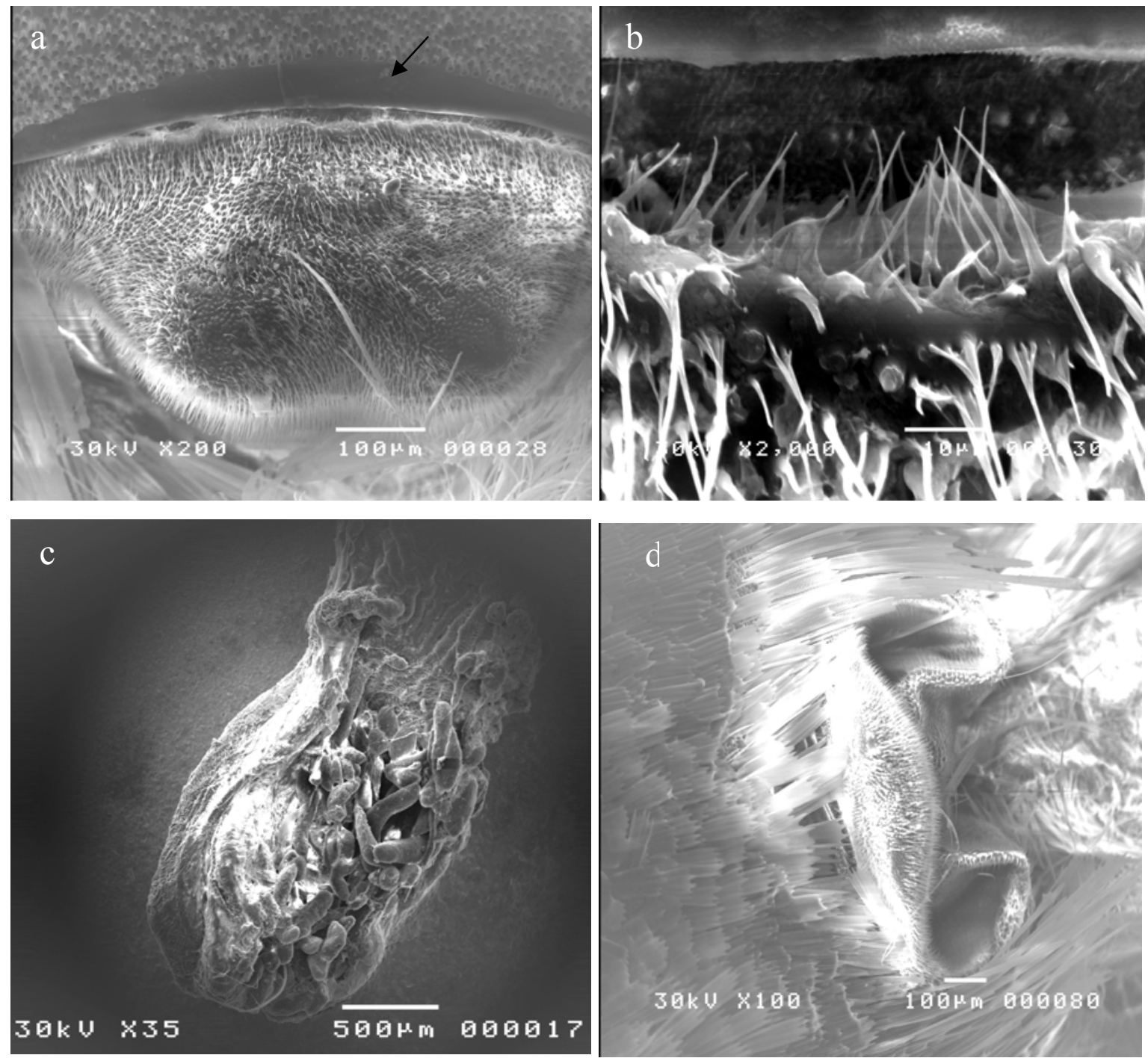

Fig.1: Scanning electron microscopy of the last abdominal segments showing: (a) The intersegmental membrane (arrow) between eighth and ninth segments; (b) The rim of the intersegmental membrane just in front of the ninth segment is covered with cuticular hairs; (c) The gland lies in the body cavity; (d) The sac in the retracted position folded in the lumen of the duct. 

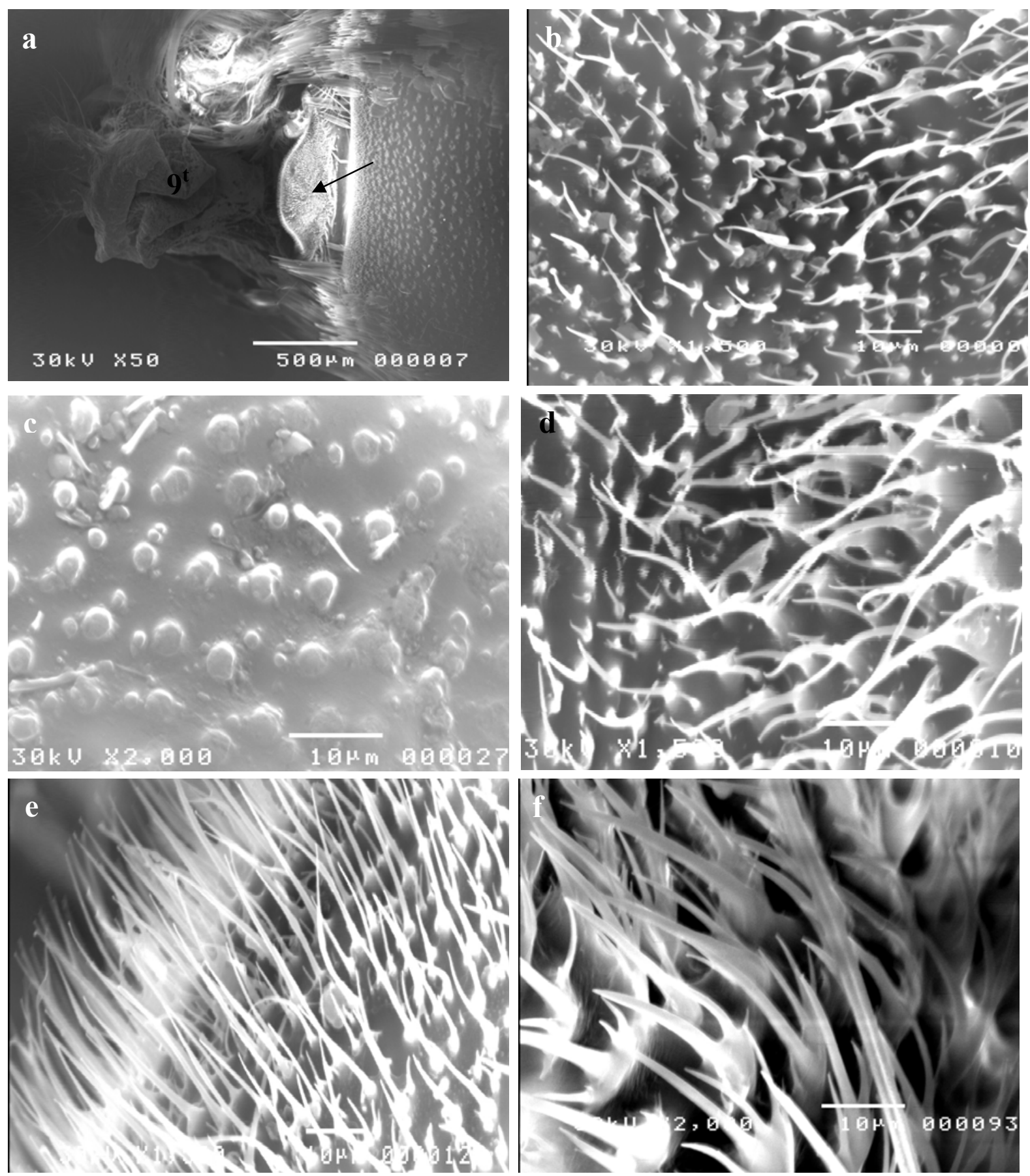

Fig. 2: Scanning electron microscopy of the last abdominal segments showing: (a) The sac in the extruded position everted and pushed out ward (arrow), $9^{\text {th }}$ segment; (b-f) Various regions showing size, density and the orientation of the cuticular hairs; (f) showing bifurcated hairs. 

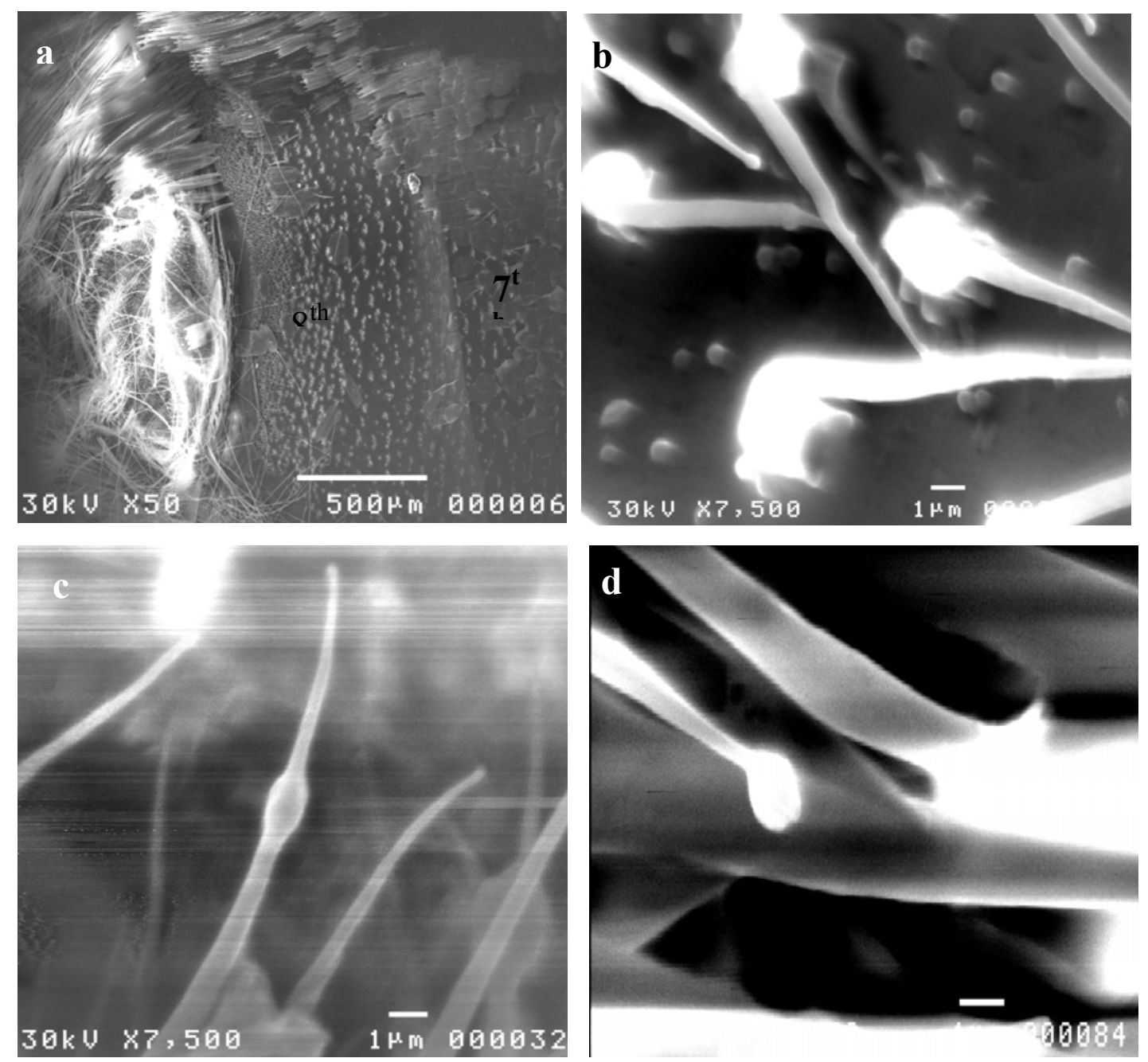

Fig. 3: Scanning electron microscopy of the last abdominal segments showing: (a) The $8^{\text {th }} \&$ $7^{\text {th }}$ abdominal segments do not show structures that produce sex pheromone; (b-d) Scanning electron microscopy of cuticular hairs in the gland area showing droplets of excretion (arrows). 


\section{ARABIC SUMMARY}

الالائل المورفولوجية للمناطق المسئولة عن إنتاج الفرومونات الخاصة بالأنثى في فراشة ورق القطن الكبرى

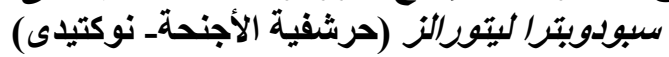

$$
\text { قسم الحيوان - كلية العلوم - جسانين زهرية سوهاج }
$$

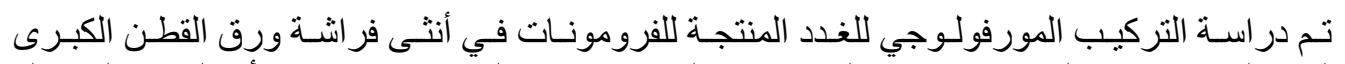

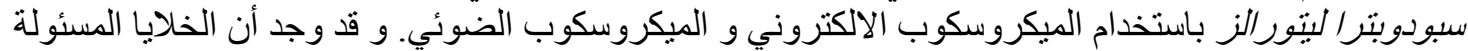

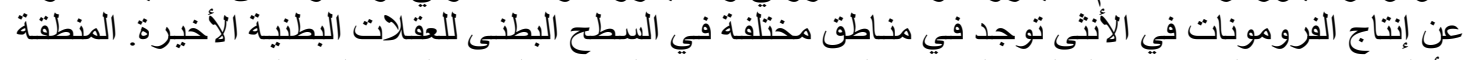

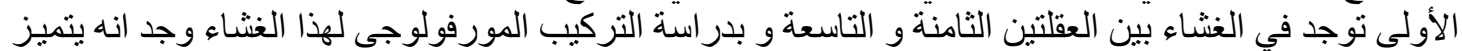

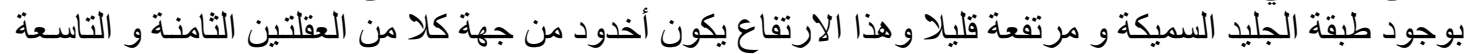

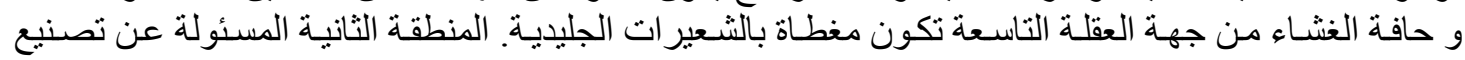

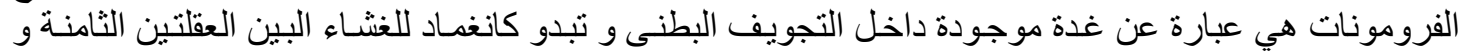

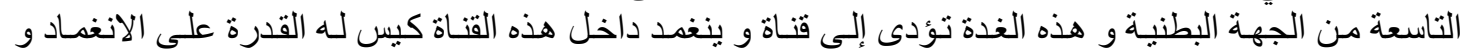

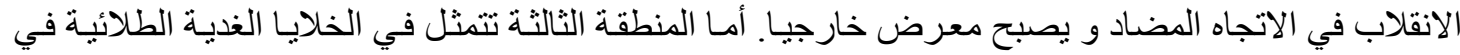

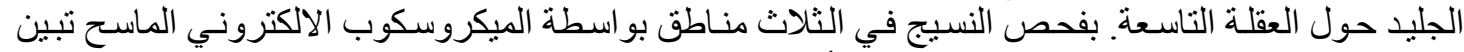
وجود قطر ات مفرزة عند قمم الشعير ات الجليدية أثناء إطلاق الفرومونات الفنات. 
